\title{
Immune responses to liver membrane antigens in patients with cystic fibrosis and liver disease
}

\author{
GIORGINA MIELI-VERGANI, HELEN T PSACHAROPOULOS, ANDREA M NICHOLSON, \\ A L W F EDDLESTON, ALEX P MOWAT, AND ROGER WILLIAMS
}

Liver Unit and Department of Child Health, King's College Hospital and Medical School, London

SUMMARY Biliary obstruction by viscid mucus, although important, may not be the only factor for the development of liver disease in some patients with cystic fibrosis. In the present study the relationship between immune responses to liver antigens and the presence of liver damage was investigated using the leucocyte migration test and lymphocyte cytotoxicity to isolated rabbit hepatocytes. Inhibition of leucocyte migration by purified liver-specific lipoprotein, derived from hepatocyte plasma membrane, was found in 9 of 11 children with liver disease, but in only 5 of 14 with cystic fibrosis and no overt liver disease $(P<0 \cdot 025)$. Lymphocyte toxicity to isolated rabbit hepatocytes was significantly increased in 10 of 13 children with liver disease, but in only 6 of 29 children without liver disease $(P<0 \cdot 001)$. Experiments using lymphocyte subpopulations showed that the cytotoxicity was mediated by a non-T-cell population and could be blocked with liver-specific lipoprotein in 7 out of 10 cases, suggesting that the reaction in these patients was specifically directed against liverspecific lipoprotein. The study suggests that sensitisation against liver membrane antigens, whether arising primarily or secondarily in some way to other hepatic lesions, may contribute to the progression of liver damage in cystic fibrosis.

About $40 \%$ of children with cystic fibrosis (CF) eventually develop abnormalities of liver function, and between 2 and $20 \%$ have been reported as having clinically significant chronic liver disease. ${ }^{1-4}$ The pathogenesis of such liver disease is unknown, although one important factor is primary biliary obstruction by viscid mucus. ${ }^{5-6}$ Some immunological abnormalities have been demonstrated in patients with $\mathrm{CF}$-such as immediate skin hypersensitivity reactions to a wide variety of allergens, raised serum IgE, precipitating antibodies to bacterial and fungal antigens, and allergens in the sputum, ${ }^{7-8}$ immune complexes in serum and sputum, ${ }^{9}$ antinuclear factors, ${ }^{10}$ and lymphocyte sensitisation against antigens, in homogenates of pancreas and lung. ${ }^{11}$ Since immune reactions against liver antigens may underlie the progressive liver damage in other forms of chronic liver disease in children, ${ }^{12}$ and in adults, ${ }^{13-15}$ we have studied, using similar test systems, children with CF with or without apparent liver disease. These systems comprised lymphocyte cytotoxicity to isolated hepatocytes and leucocyte migration inhibition in response to a liver membrane protein, liver-specific lipoprotein (LSP), one of the target antigens known to be affected in liverdirected cytotoxicity in chronic active hepatitis.

\section{Patients and methods}

The children with CF participating in this study were attending outpatient clinics at King's College Hospital, The Hospital for Sick Children, and Sydenham Children's Hospital. Their parents had agreed to further investigations being performed after they had been given full explanations of the tests.

Liver disease was considered to be present when at least two of the following parameters were abnormal: liver palpable more than $4 \mathrm{~cm}$ below the costal margin, spleen palpable more than $1 \mathrm{~cm}$ below the costal margin, aspartate transaminase (AST), gamma glutamyl transpeptidase (gamma GT), and alkaline phosphatase levels above upper limits of normal for the laboratory $(40 \mathrm{IU} / 1,45 \mathrm{IU} / 1$, and $260 \mathrm{IU} / 1$ respectively). Such clinical and biochemical evidence of liver disease was present in 14 of the 45 patients (Table). The mean age of the whole group was 9.9 (range 2-18) years, but those with liver disease tended to be older, there being an increase in the prevalence of liver disease with increasing age $(\mathbf{P}<\mathbf{0 . 0 1}$, Wilcoxon Rank test). There was no difference in the sex ratio between those with and those without liver disease. All but 2 of the children 
Table Clinical and laboratory data for children with cystic fibrosis and liver disease

\begin{tabular}{|c|c|c|c|c|c|c|c|c|c|c|}
\hline Case & Sex & $\begin{array}{l}\text { Age } \\
\text { (years) }\end{array}$ & $\begin{array}{l}\text { Liver } \\
\text { size } \\
(\mathrm{cm})\end{array}$ & $\begin{array}{l}\text { Spleen } \\
\text { size } \\
(\mathrm{cm})\end{array}$ & $\begin{array}{l}A S T \\
(I U / l)\end{array}$ & $\begin{array}{l}\operatorname{gamma} G T \\
(I U / l)\end{array}$ & $\begin{array}{l}\text { Alkaline } \\
\text { phosphatase } \\
(I U / l)\end{array}$ & $\begin{array}{l}\text { Cytotoxicity } \\
(\%)\end{array}$ & $\begin{array}{l}L M T^{*} \\
(M I)\end{array}$ & Liver biopsy \\
\hline 1 & $\mathbf{M}$ & 9 & 8 & 3 & 31 & 40 & 197 & 94 & - & \\
\hline 2 & $\mathbf{F}$ & 13 & 2 & $8 \cdot 5$ & 90 & 104 & 406 & 91 & 0.60 & \\
\hline 3 & $\mathbf{M}$ & 15 & 3 & 8 & 74 & 122 & 546 & 82 & - & \\
\hline 4 & $\mathbf{F}$ & 13 & 7 & 12 & 69 & 162 & 795 & 85 & 0.69 & $\begin{array}{l}\text { Cirrhosis. Polymorphonuclear cell } \\
\text { infiltrate in the portal tract }\end{array}$ \\
\hline 5 & $\mathbf{M}$ & 16 & $4 \cdot 5$ & 1 & 20 & 8 & 277 & 85 & 0.83 & \\
\hline 6 & $\mathbf{M}$ & 3 & $4 \cdot 5$ & 0 & 59 & 16 & 124 & 78 & 0.61 & \\
\hline 7 & $\mathbf{F}$ & 8 & 6 & 3 & 61 & 32 & 222 & 77 & 0.60 & $\begin{array}{l}\text { Cirrhosis. Mixed inflammatory } \\
\text { cells in the portal tract }\end{array}$ \\
\hline 8 & $\mathbf{F}$ & 17 & 4 & 7 & 134 & 180 & 478 & 48 & 0.77 & $\begin{array}{l}\text { Fibrosis. Dense mononuclear infiltrate } \\
\text { in the portal tract. Severe piecemeal } \\
\text { necrosis }\end{array}$ \\
\hline 9 & $\mathbf{F}$ & 13 & 5 & 16 & 56 & 108 & 324 & 10 & 0.99 & $\begin{array}{l}\text { Macronodular cirrhosis. } \\
\text { Polymorphonuclear cell infiltrate } \\
\text { in the portal tract }\end{array}$ \\
\hline 10 & $\mathbf{M}$ & 10 & 7 & 0 & 169 & 124 & 243 & 32 & 1.03 & \\
\hline 11 & $\mathbf{M}$ & 8 & 7 & 3 & 56 & 100 & 320 & 88 & 0.77 & $\begin{array}{l}\text { Fibrosis. Moderate disruption } \\
\text { limiting plate. Mixed inflammatory } \\
\text { cells in the portal tract }\end{array}$ \\
\hline 12 & $\mathrm{~F}$ & 11 & 7 & 3 & 33 & 96 & 240 & 63 & 0.75 & \\
\hline 13 & $\mathbf{M}$ & 10 & 0 & 0 & 111 & 176 & 269 & - & $0 \cdot 71$ & \\
\hline 14 & $\mathbf{M}$ & 14 & 0 & 0 & 46 & 60 & 228 & 0 & 一 & \\
\hline \multicolumn{5}{|c|}{ Normal values } & -40 & $<45$ & $<260$ & $<35$ & $>0.85$ & \\
\hline
\end{tabular}

* Leucocyte migration test (migration indices).

were being treated with pancreatic enzymes and vitamins, and 39 children were taking antibiotics.

Liver biopsy performed in 5 of the children with apparent liver disease showed severe fibrosis in all, with cirrhosis in 3 . In 1 there was a considerable mononuclear infiltrate in the portal tract and periportal areas, with severe piecemeal necrosis of periportal hepatocytes, and 2 had moderate mixed inflammatory cell infiltrates in the portal tract, associated with moderate disruption of the limiting plate in one. In the remaining 2 cases, the inflammatory cells were predominantly polymorphonuclear and the limiting plate was intact.

Children attending outpatients for a variety of disorders, who required venepunctures for investigations, served as controls (enuresis (6), failure to thrive (10), mild upper respiratory tract infection (3), abdominal pain (2), previous urinary tract infection (1), obesity (1), heart murmur (1), circumcision (1), suspected hyperparathyroidism (1), arthralgia (1), trauma (1)). None had clinical or biochemical evidence of hepatocellular disease.

Leucocyte migration test. Purified human LSP, prepared as described elsewhere, ${ }^{16}$ was used as antigen in the leucocyte migration test. The technique used for the leucocyte migration test was that described by Mitchell et al. ${ }^{17}$ Preliminary experiments showed that the highest concentration of lipoprotein which could be used in the test without obtaining nonspecific inhibition of migration was $50 \mu \mathrm{g} / \mathrm{ml}$, and this concentration was therefore used throughout the study. Migration indices were calculated as the ratios between the areas of migration in chambers with and without LSP.

The leucocyte migration test was performed in 25 of the children with CF, 13 boys and 12 girls, mean age 10 (range 2-18) years, and in 12 control children, 8 boys and 4 girls, mean age 6.7 (range 2-11) years; 11 out of the 25 children in whom the leucocyte migration test was carried out had liver disease and their mean age was $11 \cdot 7$ years.

\section{Cytotoxicity to isolated rabbit hepatocytes.}

\section{Preparation of lymphocytes}

Lymphocyte-rich plasma was obtained from $10 \mathrm{ml}$ of peripheral blood by sedimentation with $1 \mathrm{ml}$ of $6 \%$ dextran containing $100 \mu \mathrm{m}$ of preservative-free heparin. After diluting 1:1 with RPMI 1640 medium with glutamine (Flow Laboratories Ltd), plasma was incubated in a cotton-wool column at $37^{\circ} \mathrm{C}$ for 15 minutes to remove macrophages. ${ }^{18}$ The leucocytes were then centrifuged over a Ficoll/Triosil density gradient to remove the remaining neutrophils and red blood cells. ${ }^{19}$ After washing, the interface lymphocytes excluded trypan-blue and contained fewer than $1 \%$ neurophils and fewer than $5 \%$ macrophages.

Subpopulations of lymphocytes were obtained on five occasions using the technique described by Cochrane et al. ${ }^{20}$ A T-cell-enriched lymphocyte 
subpopulation was obtained by rosetting the B-cells with sheep red cells, plus antibody and complement.

The nonrosetted T-cells were collected after centrifugation over a Ficoll/Triosil density gradient. In a similar way, a non-T-cell-enriched subpopulation was obtained by rosetting the T-lymphocytes by Ficoll/Triosil centrifugation. Purity of the enriched population of lymphocytes was checked by rosetting with both E-and EAC-cells ${ }^{21}$ and by counting the percentage of T- and non-T-lymphocytes. T-cellenriched fractions were contaminated with $3,1,4,6$, and $3 \%$ of non-T cells and non-T-cell-enriched fractions with $5,16,10,6$, and $7 \%$ of T-cells.

\section{Microcytotoxicity assay}

The methods used were those described previously ${ }^{13}$ except that only collagenase was used in the enzyme solution and amphotericin $B$ was added to the culture medium in addition to the existing antibiotics. Isolated hepatocytes were prepared from a freshly-killed adult New Zealand white rabbit incubating 1-2 mm cubes of liver for 16 hours in enzyme solution. After washing with RPMI medium, the hepatocytes were seeded into wells in microtest culture plates (Falcon 3034) to achieve a final concentration of about $95 \%$ oxygen and $5 \%$ carbon dioxide for 24 hours at $37^{\circ} \mathrm{C}$. The supernatant was then aspirated from each well and replaced in 10 test chambers with $10 \mu \mathrm{l}$ lymphocytes suspended in 10 test chambers with $10 \%$ fetal calf serum. The concentration of lymphocytes was adjusted to produce a lymphocyte to hepatocyte ratio of 400:1. Medium alone was added to hepatocytes in 10 control wells. After incubation at $37^{\circ} \mathrm{C}$ for a further 48 hours the plates were inverted for 2 hours and then carefully washed with Hanks's balanced salt solution (Wellcome). The number of hepatocytes remaining in each well was counted at $\times 60$ magnification using a graticule eyepiece. The difference between the mean number of cells in control and test wells, expressed as a fraction of the former, gave the percentage toxicity. The test was performed in $\mathbf{4 2}$ of the children with CF, 25 boys and 17 girls, mean age 10 (range 2-18) years. 13 of them, with a mean age of 12 years, had liver disease. The mean percentage cytotoxicity in 16 children in the control group was $11 \%$ with a standard deviation (SD) of 12 . Cytotoxicity in excess of $35 \%$ ( 2 SDs above the mean) was considered positive.

\section{Results}

Leucocyte migration test. Significant inhibition, expressed by a migration index of less than 0.85 (2 SDs below the mean value in the control subjects) was evident in 9 out of 11 children with liver disease,

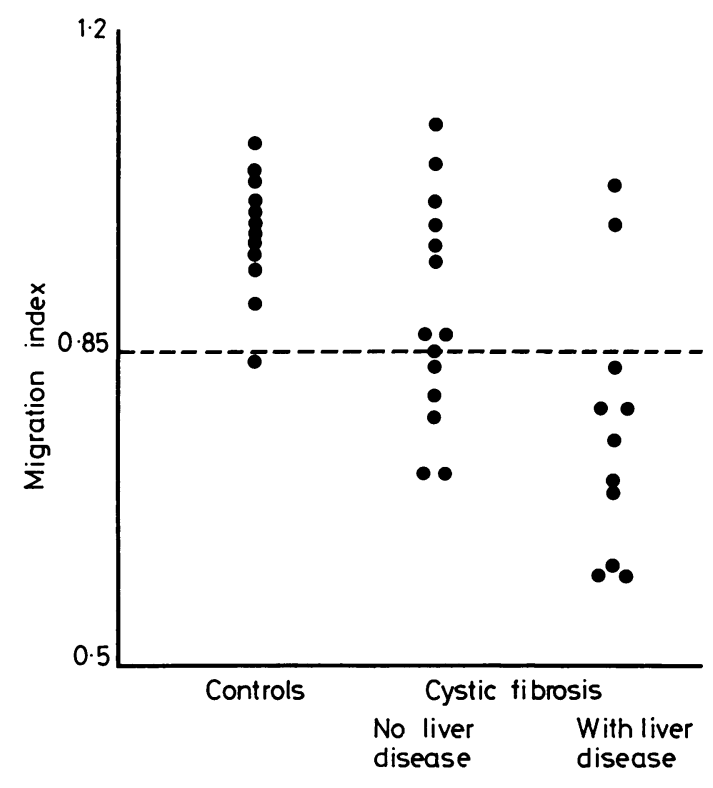

Fig. 1 Leucocyte migration test in the presence of liverspecific lipoprotein in control children and in children with cystic fibrosis with or without liver disease.

but in only 5 out of 14 children without evidence of liver disease $\left(\chi^{2}=5 \cdot 3 ; P<0.025\right.$. Fig. 1). The 9 children with liver disease and significant inhibition of migration included 4 of the 5 children with abnormal liver histology. The 1 child with abnormal liver histology and normal results to the leucocyte migration test was 1 of the 2 with predominantly polymorphonuclear cell infiltrates in portal areas and no disruption of the limiting plate.

Lymphocyte cytotoxicity. Lymphocyte cytotoxicity was positive in 10 out of the 13 patients with liver disease, but only in 6 out of the 29 children without evidence of liver disease $\left(\chi^{2}=12 ; P=<0.001\right.$, Fig. 2). When the 5 children in whom liver biopsies were carried out are considered, the same 4 in whom inhibition in the leucocyte migration test was found also showed a positive cytotoxicity, the fifth was negative.

By adding $1 \mu \mathrm{g}$ purified LSP to the microtest wells in 10 cases with positive results the cytotoxicity was greatly reduced $(P<0.01$; Wilcoxon Rank test, Fig. 3). In 7 cases the value in the presence of LSP fell to within normal range, but there were 3 patients in whom no effect could be detected.

Subpopulations of T- and non-T-lymphocytes were prepared in 5 of the cases showing cytotoxicity in the standard assay. Significant cytotoxicity was 


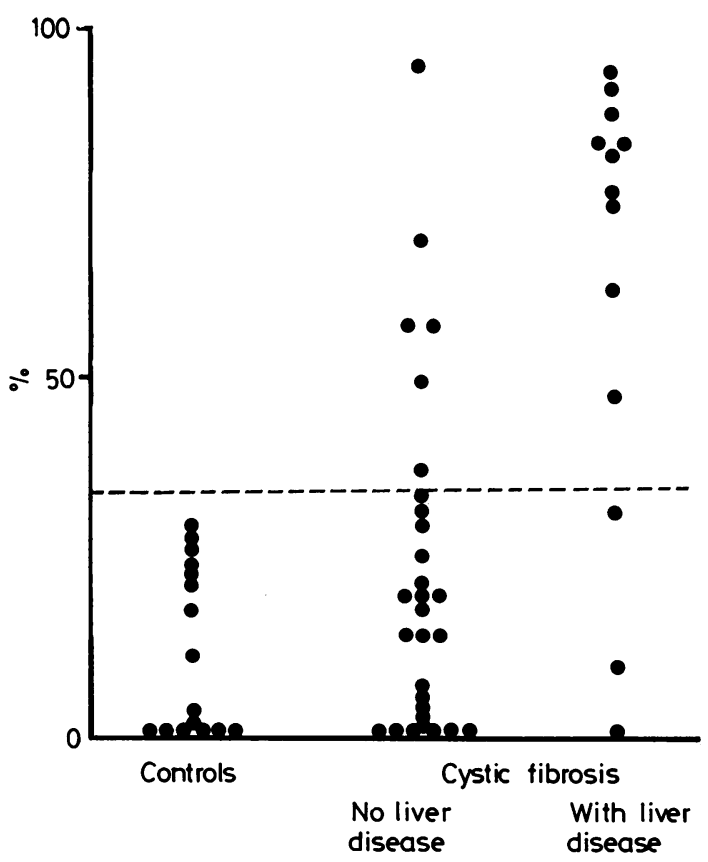

Fig. 2 Lymphocyte cytotoxicity to isolated rabbit hepatocytes in control children and in children with cystic fibrosis with or without liver disease.

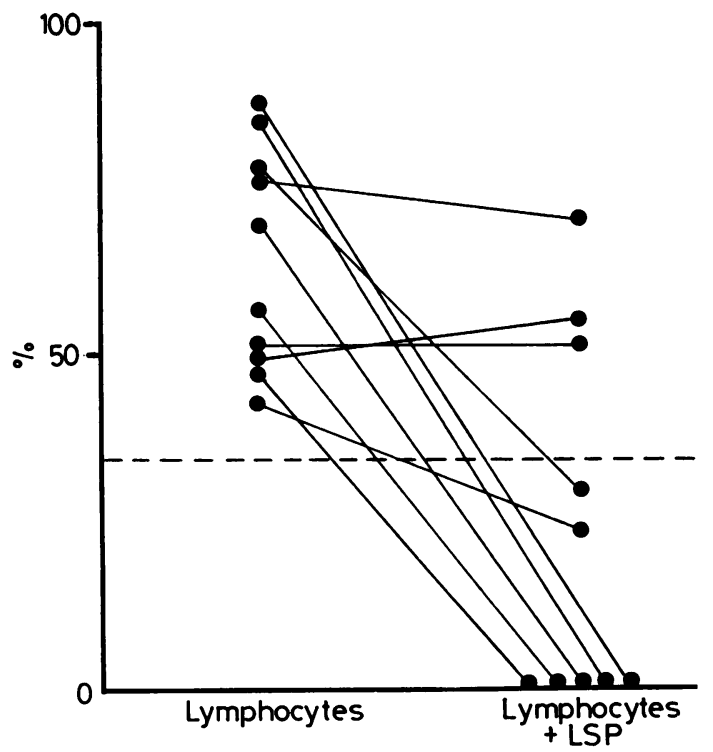

LSP liver-specific lipoprotein

Fig. 3 Effect on lymphocyte cytotoxicity if liver-specific lipoprotein is added to the microculture wells.

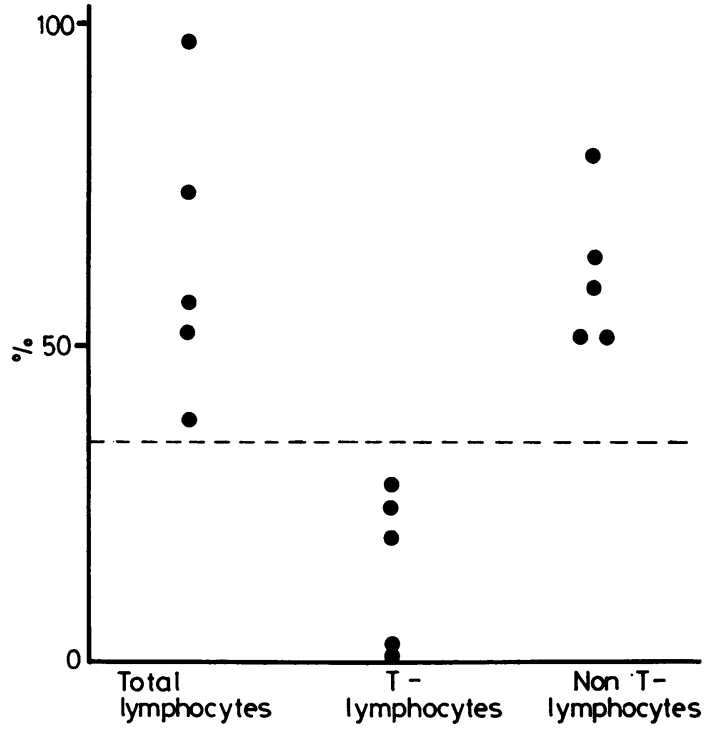

Fig. 4 Lymphocyte cytotoxicity using unfractionated lymphocytes and $T$ - or non-T subpopulations.

again observed in every case when the non-T-cells were added to the hepatocytes, while negative results were consistenly observed using the preparation enriched in T-lymphocytes (Fig. 4).

There was good agreement between the results obtained with the leucocyte migration test and lymphocyte cytotoxicity to isolated rabbit hepatocytes. Of 12 cases with significantly increased cytotoxicity, $10(83 \%)$ showed significant inhibition of leucocyte migration, while this was present in only $4(40 \%)$ of the 10 cases with normal results in the cytotoxicity assay $\left(\chi^{2}=4 \cdot 4 ; P>0 \cdot 05\right)$.

\section{Discussion}

In the present study, using in vitro inhibition of leucocyte migration in the presence of LSP and cytotoxicity of lymphocytes for isolated rabbit hepatocytes, we were able to show a clear correlation between immune reactions against liver antigens and liver disease in children with CF, particularly in those with altered liver histology. Furthermore, the results obtained with lymphocyte subpopulations in the cytotoxicity assay indicated that the effector cells are non-T-lymphocytes, since they bear receptors for complement. The same populations of cells were seen to be the in vitro effector in chronic active hepatitis and to be blocked by aggregated IgG, indicating that they also have receptors for immunoglobulin. ${ }^{20}$ In chronic active hepatitis the most 
likely mechanism responsible for the cytotoxicity is that $\mathrm{Fc}$ receptor-bearing lymphocytes, $\mathrm{K}$-cells, become attached to the hepatocytes on liver cell surface. ${ }^{22} \mathrm{~T}$-cell involvement however, has not been excluded. Indeed, it is likely that this test system, in which rabbit liver cells are incubated with human lymphocytes, is unsuitable for demonstrating T-cell cytotoxicity since it has been shown that for optimum T-cell cytotoxicity, the target cells and the effector cells must share histocompatibility determinants. ${ }^{23}$ Whatever the cellular basis, the blocking studies show that LSP is an important target cell antigen in most cases. The absence of blocking effect in three cases however, suggests that other hepatocyte membrane antigens may also be affected. The results of the leucocyte migration test provide further evidence of an immune response to LSP in many patients with liver disease complicating cystic fibrosis, but the possible cellular interactions in this test system are also complex. While inhibition of leucocyte migration can indicate the presence of sensitised T-cells, it may also be mediated by cellbound antibodies. ${ }^{24}$

The frequency of liver disease in $C F$ varies considerably but this is at least partly related to the sensitivity of the tests used in the assessments. An abnormal liver scan has been found in $40 \%,{ }^{1}$ raised alkaline phosphatase concentrations in $47 \%$ of patients older than 16 years, ${ }^{2}$ and high gamma GT in $30-60 \%{ }^{25}$ Clinically apparent liver disease ranges from sporadic observations ${ }^{426}$ to $20 \%$ in series. ${ }^{3}$ Dietzsch et al., ${ }^{27}$ who performed liver biopsies in a large series of children with $C F$, before clinical evidence of liver disease became apparent and in some cases before there were biochemical changes, found the characteristic hepatic abnormalities of CF (portal fibrosis, bile duct dilatation, and mild to severe cholangitis) in $9(11.7 \%)$ out of 77 children. Of the remaining 68 patients however, $25 \%$ had 'unspecific reactive hepatitis' and $40 \%$ had fatty changes. Furthermore, Feigelson et al. ${ }^{28}$ recently stressed that children with $\mathrm{CF}$ and clinically apparent liver involvement $(16 \%)$ may have two different types of cirrhosis, one being of the cholestatic type and the other with little or no cholestasis. In the present study we noted considerable variation in the character of the cellular infiltrate in the liver biopsies reviewed, ranging from a predominance of polymorphonuclear leucocytes and intact limiting plate on the one hand, to a dense mononuclear infiltrate extending into the lobules on the other. The latter features are similar to those seen in chronic active hepatitis, and in adults with this condition there is a close relationship between these histological abnormalities and both cellular and humoral immune reactions against liver antigens. Indeed, in rabbits repeated immunisation with liver-specific lipoprotein is associated with the development of similar changes in liver histology which can progress to cirrhosis. ${ }^{29}$ Thus, while biliary obstruction by viscid mucus may be an important factor in determining liver involvein CF, sensitisation against LSP and other liver cell membrane antigens, whether arising primarily or, more likely, due to genetic predisposition and triggered by environmental factors, may contribute to the progression of liver damage.

We thank the children and their parents for enthusiastic support and co-operation in this study, also Dr A P Norman and Dr R Dinwiddie, The Hospital for Sick Children, Great Ormond Street, and Dr P G Wallis, Sydenham Children's Hospital, who kindly allowed us to see patients under their supervision.

HTP and AMN were supported by a grant from the Cystic Fibrosis Research Trust and the work was financed by a grant from The Wellcome Trust.

G M-V took part in this work while still attached to The Clinica Pediatrica 2, Universita Di Milano, Italy.

\section{References}

1 Feigelson J, Pecau Y, Perez R. Liver scanning and liver function in cystic fibrosis. Acta Paediatr Scand 1972; 61: $337-42$.

2 Boat T F, Doershuk C F, Stern R C, Matthews L W. Serum alkaline phosphatase in cystic fibrosis-interpretation of elevated values based on electrophoretic isoenzyme analyses. Clin Pediatr (Phila) 1974; 13: 505-12.

3 Tyson K R T, Schuster S R, Shwachman H. Portal hypertension in cystic fibrosis. J Pediatr Surg 1968; 3: 271-7.

4 Stern R C, Stevens D P, Boat T F, Doershuk C F, Izant R J, Jr, Matthews L W. Symptomatic hepatic disease in cystic fibrosis: incidence, course, and outcome of portal systemic shunting. Gastroenterology 1976; 70: 645-9.

5 Mowat A P. Liver disease in cystic fibrosis. Maandschr Kindergeneesk 1975; 43: 298-305.

- Oppenheimer E H, Esterly J R. Hepatic changes in young infants with cystic fibrosis: possible relation to focal biliary cirrhosis. J Pediatr 1975; 86: 683-9.

7 Allan J D, Moss A D, Wallwork J C, McFarlane H. Immediate hypersensitivity in patients with cystic fibrosis. Clin Allergy 1975; 5: 255-61.

8 Wallwork J C, Brenchley P, McCarthy J, et al. Some aspects of immunity in patients with cystic fibrosis. Clin Exp Immunol 1974; 18: 303-20.

- McFarlane H, Holzel A, Brenchley P, et al. Immune complexes in cystic fibrosis. $\mathrm{Br} \mathrm{MedJ} 1975$; i: 423-8.

10 Høiby N, Wiik A. Antibacterial precipitins and autoantibodies in serum of patients with cystic fibrosis. Scand $J$ Respir Dis 1975; 56: 38-46.

11 Gibbons A, Allan J D, Holzel A, McFarlane H. Cellmediated immunity in patients with cystic fibrosis. $B r$ Med J 1976; i: 120-2. 
12 Smith A L, Cochrane A M G, Mowat A P, Eddleston A L W F, Williams R. Cytotoxicity to isolated rabbit hepatocytes by lymphocytes from children with liver disease. J Pediatr 1977; 91 : 584-96.

13 Thomson A D, Cochrane A M G, McFarlane I G, Eddleston A L W F, Williams R. Lymphocyte cytotoxicity to isolated hepatocytes in chronic active hepatitis. Nature 1974; 252 : 721-2.

14 Cochrane A M G, Moussouros A, Smith A, Portmann B, Eddleston A L W F, Williams R. Lymphocyte cytotoxicity in chronic active hepatitis: effect of therapy and correlations with clinical and histological changes. Gut 1978; 19: 308-14.

15 Cochrane A M G, Moussouros A, Portmann B, et al. Lymphocyte cytotoxicity for isolated hepatocytes in alcoholic liver disease. Gastroenterology 1977; 72: 918-23.

16 McFarlane I G, Wojcicka B M, Zucker G M, Eddleston A L W F, Williams R. Purification and characterisation of human liver-specific membrane lipoprotein (LSP). Clin Exp Immunol 1977; 27: 381-90.

17 Mitchell C G, Smith M G M, Golding P L, Eddleston A L W F, Williams R. Evaluation of the leucocyte migration test as a measure of delayed hypersensitivity in man. Clin Exp Immunol 1972; 11 : 535-41.

18 Rocklin $R$ E, Meyer O L, David J R. An in vitro assay for cellular hypersensitivity in man. J Immunol 1970; 104: 95-102.

19 Böyum A. Isolation of leucocytes from human blood. A two-phase system for removal of red cells with methylcellulose as erythrocyte-aggregating agent. Scand J Clin Lab Invest 1968; 21 : Supplement 97, 9-29.

20 Cochrane A M G, Moussouros A, Thomson A D, Eddleston A L W F, Williams R. Antibody dependent cell-mediated ( $\mathrm{K}$ cell) cytotoxicity against isolated hepatocytes in chronic active hepatitis. Lancet 1976; i: 441-4.

21 Stjernsward J, Jondal M, Vanky F, Wigzell H, Sealy R. Lymphopenia and change in distribution of human $B$ and $T$ lymphocytes in peripheral blood induced by irradiation for mammary carcinoma. Lancet 1972; i: 1352-6.
22 Gonzales C, Cochrane A M G, Eddleston A L W F, Williams $R$. Mechanisms responsible for antibodydependent cell-mediated cytotoxicity to isolated hepatocytes in chronic active hepatitis. Gut 1979; 20 : 385-8.

23 Zinkernagel $R$ M, Doherty $P$ C. Restriction of in vitro $\mathrm{T}$-cell-mediated cytotoxicity in lymphocytic choriomeningitis within a syngeneic or semiallogeneic system. Nature 1974; 248: 701-2.

24 Brostoff J. Critique of present in vitro methods for the detection of cell-mediated immunity. Proc Roy Soc Med 1974 ; 67 : 514-6.

25 Isenberg J N, L'Heureux P, Warwick W J, Sharp H L. Detection of cirrhosis in cystic fibrosis; lack of correlation with gamma glutamyl transpeptidase and biliary tract roentgenograms (abstract). Gastroenterology 1974; 66: 887.

26 Shwachman H, Kulczycki L L, Kon-Taik Khaw. Studies in cystic fibrosis. A report on sixty-five patients over 17 years of age. Pediatrics $1965 ; 36$ : 689-99.

27 Dietzsch H J, Himkel G K, Roschlau G. Liver involvement in cystic fibrosis: clinical, bioptic, and laboratory follow-up studies. In: Proceedings of the VIIth International Cystic Fibrosis Congress, Paris, June 1976. Paris: Imprimerie, 1976: 470-3.

28 Feigelson J, Pecau Y, Cathelineau L, Navarro J. L'atteinte hépatique dans la mucoviscidose. In: Proceedings of the VIIth International Cystic Fibrosis Congress, Paris, June 1976. Paris: Imprimerie, 1976: 451-62.

29 Meyer zum Büschenfelde $K \mathbf{H}$, Hopf U. Studies on the pathogenesis of experimental chronic active hepatitis in rabbits. I. Induction of the disease and protective effect of allogeneic liver specific proteins. Br J Exp Pathol 1974; 55 : 498-508.

Correspondence to Dr A P Mowat, Department of Child Health, King's College Hospital and Medical School, Denmark Hill, London SE5 8RX.

Received 31 July 1979 